\title{
THE IMPACT OF CLINICAL PATHWAY IMPLEMENTATION ON LENGTH OF STAY AND HOSPITAL COST: A SYSTEMATIC REVIEW
}

\author{
Herlin Putri Tanjung, Atik Nurwahyuni \\ Faculty of Public Health, Universitas Indonesia
}

\begin{abstract}
Background: Clinical Pathway (CP) is a method of clinical documentation that reflects clinical practice standards for physicians, nurses, and other members of healthcare team. Clinical pathways are increasingly being used by hospitals to improve efficiency in the care of certain patient populations. This study aimed to review systematically the impact of CP implementation on length of stay and hospital cost.

Subjects and Method: A systematic review was conducted by searching published articles from 2010 to 2019 from databases including: Proquest, Scopus, and Pubmed. The keywords for this review "impact, implementation, clinical pathways, critical pathways, care pathways, integrated care pathways, hospital costs and length of stay". The dependent variables were length of stay and hospital cost. The independent variable was CP. There were 7 articles obtained after implementing the inclusion criteria.

Results: There was a significant reduction in hospital costs and length of stay after the implementation of CP. There was no significant difference between before and after the application of $\mathrm{CP}$ in aspects of complication, mortality, readmission, and clinical outcome.

Conclusion: Implementation of $\mathrm{CP}$ can significantly reduce hospital length of stay and cost without reducing the quality of health service.
\end{abstract}

Keywords: clinical pathway, length of stay, hospital cost

\section{Correspondence:}

Herlin Putri Tanjung. Faculty of Public Health, Universitas Indonesia, Depok, West Java. Email: drherlinputri@gmail.com. Mobile: 081584203086.

\section{BACKGROUND}

In the era of medical care competition in treating patients, a doctor wants to provide maximum and varied services according to the knowledge he has. This variation is sometimes needed, but not infrequently provided is an unnecessary service and risks to burden the patient, especially in terms of cost, this condition can be controlled by the application of clinical pathway as the most popular initiative to reduce costs and length of stay can even improve the quality of care and patient satisfaction (Pearson et al., 1995; Rahma, 2013).

Clinical pathway (CP) is a structured multidisciplinary treatment plan with minimum service standards that shows in detail the important stages of health care from receiving patients to returning patients, ensuring that no services are forgotten and implemented on time (Kinsman et al., 2010; Lawal et al., 2010; Rahma, 2013). Clinical pathway aims to improve patient outcomes, improve patient safety, improve quality of care, reduce risk, increase patient satisfaction, reduce length of stay and costs and optimize resources (Ban et al., 2012; De Bleser et al., 2006; Luc \& Kitchiner, 2001; Rotter et al., 2008).

Clinical pathway has many other names such as: Critical Care Pathway, Integrated Care Pathways (ICPs), Coordinated Care Pathways, Caremaps, Anticipated Recovery Pathways (ARPs), Critical Care Pathways, Clinical Pathways, Care Tracks, 
Clinical Care Pathways, Critical Care Pathways Method, Clinical Algorithm, Multidisciplinary Pathways of Care (MPC), Care Protocols, Care Models, Evidence-based Care, Collaborative Care Plans, but in the UK the terms Clinical Pathway and Integrated Care Pathways are most often used (Bayliss et al., 2009; Kinsman et al., 2010; Luc \& Kitchiner, 2001; Rahma, 2013).

The United States first implemented clinical pathway (CP) in the 1980 s to standardize the results of care and control costs, in the late 1980s, the application of CP in the UK for reasons of quality improvement (Bayliss et al., 2009).

Although the effectiveness of CP was still being argued, the use of CP has spread to various countries in the United States, Australia, Canada, Europe and Asia, $80 \%$ of hospitals in the United States have applied CP to several diseases (Rotter et al., 2008).

Although there have been many studies on the impact of CP implementation, various results have been obtained. This systematic review is to find out the impact of the implementation of Clinical Pathway on length of stay and hospital costs in several cases of the disease.

\section{SUBJECTS AND METHOD}

\section{Study Design}

This study was a systematic review of articles on the impact of clinical pathway implementation on length of stay and hospital costs. In the search for articles, it used a database of PubMed, Scopus, and ProQuest with keywords "impact" AND "implementation" AND "clinical pathways" OR "critical pathways" OR "care pathways" OR "integrated care pathways" AND "hos- pital costs" AND "length of stay".

\section{Inclusion and Exclusion Criteria}

Inclusion criteria is the impact of implementing clinical pathway on length of stay and hospital costs, research comparing care before and after application of clinical pathway, English language articles and articles can be accessed, while exclusion criteria are systematic review methods, only assessing one of the variables. Searches were limited to English language articles and published from 2010 to 2019 and open journal access.

\section{Article Extraction}

The initial identification process based on the search limit found 125 articles and 7 articles according to the eligibility criteria would be reviewed. The systematic review process used the PRISMA (Prefer-red Reporting Items for Systematic Reviews and Meta-analysis) protocol. The search and selection process is explained in Figure 1.

\section{RESULTS \\ The grouping of important data in articles was done by analyzing data based on title, author's name, country, journal, method and results. The results of data extraction can be seen in table 1 . \\ 1. Impact on length of stay and costs after applying $\mathrm{CP}$}

Overall studies consisting of 6 invasive treatments and 1 non-invasive treatment prove that there was a reduction in hospital days and total hospital costs after applying CP (Bartlett et al., 2017; Chung et al., 2012; Kagedan et al., 2017; Lin et al., 2011; Peng et al., 2018; Zhang et al., 2019; Zhu et al., 2014). Can be seen in Table 2. 

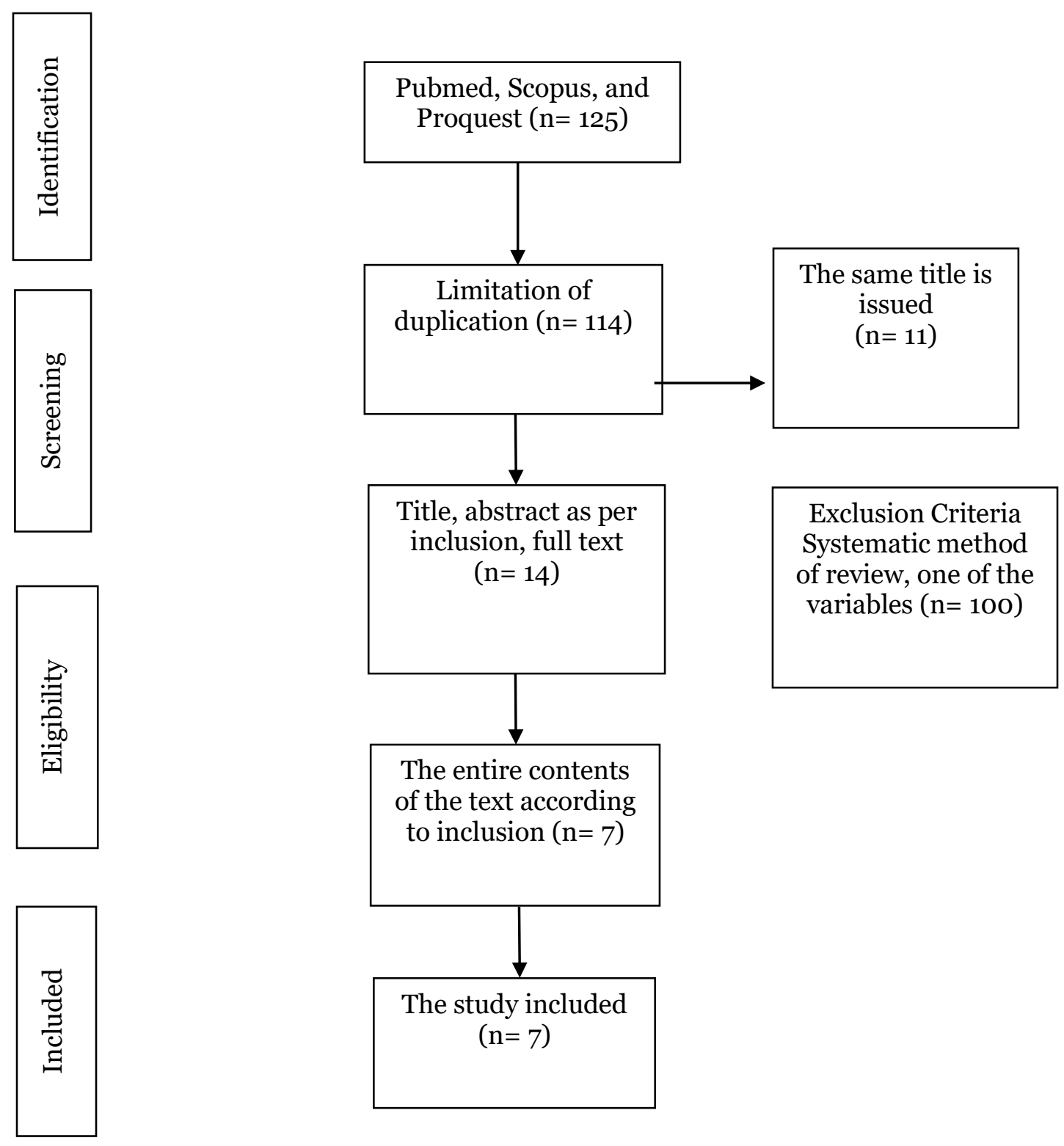

Figure 1. PRISMA Flow Diagram

Table 2. The impact after applying CP to the length of stay and hospital costs.

\begin{tabular}{|c|c|c|c|c|}
\hline \multirow[t]{2}{*}{ Authors } & \multirow[t]{2}{*}{ Cases } & \multirow[t]{2}{*}{ Total Sample } & \multicolumn{2}{|c|}{ After CP } \\
\hline & & & LOS & Cost \\
\hline \multicolumn{5}{|l|}{ Invasive Treatment } \\
\hline Zhu et al (2014) & Hepatocellular Carcinoma & 133 & $\downarrow$ & $\downarrow$ \\
\hline Zhang et al (2019) & Common Bile Duct Stones & 2663 & $\downarrow$ & $\downarrow$ \\
\hline Chung et al (2012) & Lumbar laminectomy & 119 & $\downarrow$ & $\downarrow$ \\
\hline Lin et al (2011) & Heart resection & 117 & $\downarrow$ & $\downarrow$ \\
\hline Peng et al (2018) & Uterine Leiomyoma & 1432 & $\downarrow$ & $\downarrow$ \\
\hline Kagedan et al (2017) & Pancreaticoduodenectomy & 195 & $\downarrow$ & $\downarrow$ \\
\hline \multicolumn{5}{|c|}{ Non-invasive treatment } \\
\hline Bartlett et al (2017) & Asthma Children & 297 & $\downarrow$ & $\downarrow$ \\
\hline
\end{tabular}




\section{Other impacts}

There were no significant differences in patient clinical characteristics, postoperative complications, mortality and readmission between the CP and non-CP groups. (Lin et al., 2011; Zhu et al., 2014; Bartlett et al., 2017; Kagedan et al., 2017; Zhang et al., 2019). Antibiotic use and complications in the CP group were significantly lower than those in the non-CP group in common bile duct stones patients undergoing retrograde cholangiopancreatography (ERCP) endoscopy (Zhang et al., 2019). The level of patient satisfaction was increased after the application of CP (Chung et al., 2012).

\section{DISCUSSIONS}

This study was not limited to certain diseases to see the impact of clinical pathway (CP). The application of $\mathrm{CP}$ was an effective way of maintaining the quality of medical care, minimizing unnecessary practices so as to minimize risk, practice evidence-based care, reduce length of stay and hospital costs. It can also improve treatment efficiency and has been widely applied in surgical and non-surgical cases, especially for high volume disease cases. (Bryan et al., 2017; Dey et al., 2013; Jeong et al., 2011; Luc \& Kitchiner, 2001; Pearson et al., 1995; Sung et al., 2013).

All these systematic review studies reported significant reductions in hospital stay and hospital costs when compared between before and after CP application. This was in line with 22 studies on joint replace- ment cases (Barbieri et al., 2009), cases of supracondylar humerus fractures in pediatric patients by electronic medical record methods (Sung et al., 2013) and 17 studies conducted by Rotter (2008) on the effects CP. Length of stay and costs showed a positive impact, especially length of stay in invasive care decreased significantly and there was no evidence of differences in complications and readmission.

However, in the case of gastrectomy, $\mathrm{CP}$ cannot be applied because most upper gastrointestinal operations often have postoperative complications and require additional medical care when compared to non-intestinal or non-invasive diseases, according to Jeong's pre-operative consultation and pre-operative examinations in outpatients have a significant impact on LOS and costs (Jeong et al., 2011).

Whereas 7 studies on the treatment of CP heart failure had an impact on the reduction in length of stay and death rates but there were no differences in the costs of hospitalization and readmission. (Kul et al., 2012). 
Table 1. Data extraction results

\begin{tabular}{|c|c|c|c|c|c|c|}
\hline No & Title & Author & Country & Journal & Method & $\begin{array}{c}\text { Results } \\
\text { CP vs Non-CP }\end{array}$ \\
\hline 1 & $\begin{array}{l}\text { Impact of a Clinical } \\
\text { Pathway on Hospital } \\
\text { Costs, Length of Stay } \\
\text { and Early Outcomes } \\
\text { after Hepatectomy for } \\
\text { Hepatocellular } \\
\text { Carcinoma }\end{array}$ & $\begin{array}{l}\text { Liang Zhu et al. } \\
\text { (2014) }\end{array}$ & China & $\begin{array}{l}\text { Asian Pacific } \\
\text { Journal of } \\
\text { Cancer } \\
\text { Prevention }\end{array}$ & $\begin{array}{l}\text { Retrospective and } \\
\text { prospective Study }\end{array}$ & $\begin{array}{l}\text { - Length of stay decreased by } 12.3 \text { vs } 8,3 \\
\text { days }(\mathrm{p}<0.001) \text {. } \\
\text { - } \text {-Hospital costs were reduced from } \\
24.844 \text { RMB to } 19.761 \text { RMB }(\mathrm{p}<0.01) \\
\text { - There were no significant differences: } \\
\text { patient clinical characteristics, } \\
\text { postoperative complications, mortality } \\
\text { and readmission. }\end{array}$ \\
\hline 2 & $\begin{array}{l}\text { Big-data analysis: A } \\
\text { clinical pathway on } \\
\text { endoscopic retrograde } \\
\text { cholangiopancreatogra } \\
\text { phy for common bile } \\
\text { duct stones }\end{array}$ & $\begin{array}{l}\text { Wei Zhang et al. } \\
\text { (2019) }\end{array}$ & China & $\begin{array}{l}\text { World Journal } \\
\text { of } \\
\text { Gastroenterolo } \\
\text { gy }\end{array}$ & $\begin{array}{l}\text { Retrospective Study } \\
\text { using univariate and } \\
\text { multivariable regression/ } \\
\text { linear }\end{array}$ & $\begin{array}{l}\text { - Length of stay decreased ( } \mathrm{P}<0.001) \\
\text { - Hospital costs decreased: } \\
\text { Hospitalization, surgery, care, } \\
\text { medication, and medical consumption } \\
\text { materials }(\mathrm{P}<0.001) \text {. } \\
\text { - Antibiotic use and complications } \\
\text { decreased. } \\
\text { - There were no significant differences: } \\
\text { clinical outcome, readmission, level of } \\
\text { secondary surgery. }\end{array}$ \\
\hline 3 & $\begin{array}{l}\text { Implementation and } \\
\text { outcomes of a critical } \\
\text { pathway for lumbar } \\
\text { laminectomy or micro } \\
\text { discectomy }\end{array}$ & $\begin{array}{l}\text { Sang-Bong } \\
\text { Chung et al } \\
\text { (2012) }\end{array}$ & $\begin{array}{l}\text { South } \\
\text { Korea }\end{array}$ & $\begin{array}{l}\text { Journal of } \\
\text { Korean } \\
\text { Neurosurgical } \\
\text { Society }\end{array}$ & Retrospective Study & $\begin{array}{l}\text { - Length of stay of } 5.4 \text { days vs. } 6.9 \text { days, } \\
\text { reduction of } 20 \%,(\mathrm{p} \leq 0.000) \text {. } \\
\text { - Total hospital costs decreased } \\
\text { insignificantly }(\mathrm{p}=0.815) \text {. } \\
\text { - Significant reduction in bed and } \\
\text { maintenance costs }(\mathrm{p}=0.002) \\
\text { - Increases in drug and prescription } \\
\text { costs and operating-related costs were } \\
\text { not significant. } \\
\text { - The level of patient satisfaction }\end{array}$ \\
\hline
\end{tabular}

The $6^{\text {th }}$ International Conference on Public Health Best Western Premier Hotel, Solo, Indonesia, October 23-24, 2019 | 392 https://doi.org/10.26911/the6thicph-FP.04.22 
4 Implementation of a Fast-Track Clinical Pathway Decreases Postoperative Length of Stay and Hospital Charges for Liver Resection

5 Can single disease payment system based on clinical pathway reduce hospitalization costs in rural area? A case study of uterine leiomyoma in Anhui, China

6 Improving the Efficiency of Care for Pediatric Patients Hospitalized With Asthma

7 The economics of recovery after pancreatic surgery: detailed cost minimization analysis of an enhanced recovery program

\section{De-Xin Lin et al \\ China}

(2011)

Cell

Biochemistry and Biophysics

Retrospective Study

Jing Peng et al. China

(2018)

Kathleen W.

Bartlett et al.

(2017)

Daniel J.

Kagedan et al.

(2017)

Canada

$\mathrm{Hpb}$

(Hepato-

Pancreato-

Billier) increased

- The duration of postoperative care decreased (7 vs 11 hari, P < 0.01)

- Perioperative hospital costs decreased from 26.626 RMB to 21.004 RMB (P < 0.05).

Less postoperative complications .

- - There were no significant differences: morbidity, mortality and readmission

- Length of stay decreased from 9,96 \pm 2,39 days to $8,83 \pm 1,95$ days $(\mathrm{p}<0.01$ ).

- Total inpatient costs decreased from $919,08 \pm 272,92$ USD to $834,92 \pm$ 225,29 USD.

- Costs of medication, care, testing were reduced, while the costs of surgery and examinations were increased.

- Length of stay decreased from 2,9 days to 2,3 days .

- Costs indicate savings \$1543 per cases.

- Readmission remain stable.

Cohort Retrospective

- Length of stay decreased (9 vs 11 days, $\mathrm{p}=0.005$ )

- Total post-operative hospital costs decreased (CAD \$ 15.678,45 vs CAD \$ 25.732,85, $\mathrm{p}=0.024)$, Significant cost savings areas include laboratory tests and imaging investigations.

The $6^{\text {th }}$ International Conference on Public Health Best Western Premier Hotel, Solo, Indonesia, October 23-24, $2019 \mid 393$ 
CP compliance factors also play a role in reducing the length of stay and hospital costs, this has been proven by studies conducted by Bartlett (2017) in cases of pediatric asthma and Bryan (2017) cases of bronchiolitis. In a study in 54 hospitals in Hubei Province and Gansu Province in China, the positive effect of CP was not felt by most hospitals or managers or doctors there, this was due to low involvement and adherence to $\mathrm{CP}$, but 5 hospitals showed that compliance against national CP can reduce the length of days of stay and medical costs of hospitalization (Bai, Bai, Zhu, \& Xue, 2018).

The health financing system in each country required hospital management to be able to streamline costs and control quality through the implementation of clinical pathways (Peng et al., 2018).

It can be concluded that implementing CP can result in cost savings by reducing unnecessary investigations, reducing length of stay and improving the quality of care through standardization of processes and reducing variations in practice without reducing the quality of health services. Compliance with CP implementation is important so that positive impacts can be felt. Clinical pathway must be widely implemented, with clinical pathway implementation it is expected that patients will receive services as needed, costs incurred in accordance with the care received and results as expected.

\section{REFERENCES}

Bai J, Bai F, Zhu H, Xue D (2018). The perceived and objectively measured effects of clinical pathways' implementation on medical care in China. PLoS ONE, 13(5): 1-13. https://doi.org/10.1371/journal.pone.0196776

Ban A, Ismail A, Harun R, Abdul Rahman
A, Sulung S, Syed Mohamed A(2012). Impact of clinical pathway on clinical outcomes in the management of COPD exacerbation. BMC Pulmonary Medicine, 12, 27. https://doi.org/http://dx.doi.org/10.1186/1471-2466-12-27

Barbieri A, Vanhaecht K, Van Herck P, Sermeus W, Faggiano F, Marchisio S, Panella M(2009). Effects of clinical pathways in the joint replacement: A metaanalysis. BMC Medicine, 7: 1-11. https://doi.org/10.1186/1741-7015-732

Bartlett KW, Parente VM, Morales,V, Hauser J, McLean HS (2017). Improving the Efficiency of Care for Pediatric Patients Hospitalized With Asthma. Hospital Pediatrics, 7(1): 31-38. https://doi.org/10.1542/hpeds.20160108

Bayliss V, Locke R, Salter E (2009). Continence care pathways.

Bryan MA, Desai AD, Wilson L, Wright DR, Mangione-Smith R (2017). Association of Bronchiolitis Clinical Pathway Adherence With Length of Stay and Costs. Pediatrics, 139(3): e20163432. https://doi.org/10.1542/peds.20163432

Chung SB, Lee SH, Kim ES, Eoh W (2012). Implementation and outcomes of a critical pathway for lumbar laminectomy or microdiscectomy. Journal of Korean Neurosurgical Society, 51(6): 338-342. https://doi.org/10.3340/jkns.2012.51.6.338

De Bleser L, Depreitere R, De Waele K, Vanhaecht K, Vlayen J, Sermeus W (2006). Defining pathways. Journal of Nursing Management, 14(7): 553-563. https://doi.org/10.1111/j.1365-2934.2006.00702.x

Dey B, Mitra A, Prakash K, Basu A, Ray S, Mitra A (2013). Effectiveness of Care Pathways in Ideal Hospital Manage- 
ment System: A Review. Indo Global Journal of Pharmaceutical Sciences, 3(3): 185-191.

Jeong SH, Yoo MW, Yoon HM, Lee HJ, Ahn HS, Cho JJ, Yang H K, et al. (2011). Is the critical pathway effective for the treatment of gastric cancer? Journal of the Korean Surgical Society, 81(2): 96103. https://doi.org/10.4174/jkss.2011.81.2.96

Kagedan DJ, Devitt KS, Tremblay StGermain A, Ramjaun A, Cleary SP, Wei $A C$ (2017). The economics of recovery after pancreatic surgery: detailed cost minimization analysis of an enhanced recovery program. HPB, 19(11): 10261033. https://doi.org/10.1016/j.hpb.2017.07.013

Kinsman L, Rotter T, James E, Snow P, Willis $J$ (2010). What is a clinical pathway? Development of a definition to inform the debate. BMC Medicine, 8(1): 31. https://doi.org/10.1186/17417015-8-31

Kul S, Barbieri A, Milan E, Montag I, Vanhaecht K, Panella M (2012). Effects of care pathways on the in-hospital treatment of heart failure: a systematic review. BMC Cardiovascular Disorders, 12, 81. https://doi.org/http://dx.doi.org/10.1186/1471-2261-12-81

Lawal AK, Rotter T, Kinsman L, Machotta A, Ronellenfitsch U, Scott SD, Groot G, et al. (2016). What is a clinical pathway? Refinement of an operational definition to identify clinical pathway studies for a Cochrane systematic review. BMC Medicine, 14(1): 1-5. https://doi.org/10.1186/s12916-016-0580-Z

Lin D, Li X, Ye Q, Lin F, Li L, Zhang Q (2011). Implementation of a FastTrack Clinical Pathway Decreases Postoperative Length of Stay and Hospital Charges for Liver Resection. Cell Biochemistry and Biophysics, 61(2): 413-
419. http://dx.doi.org/10.1007/s12013-011-9203-7

Luc K.De, Kitchiner D (2001). Developing Care Pathways In collaboration with. Radcliffe Medical Press Ltd.

Pearson SD, Goulart-Fisher D, Lee TH (1995). Critical Pathways as a Strategy for Improving Care: Problems and Potential. Annals of Internal Medicine, 123(12): 941-948. https://doi.org/10.7326/0oo3-4819-123-12-19951215000008

Peng J, Zhang M, Yu P, Wang N (2018). Can single disease payment system based on clinical pathway reduce hospitalization costs in rural area? A case study of uterine leiomyoma in Anhui, China. BMC Health Services Research, 18(1): 1-7. https://doi.org/10.1186/s12913-018-3807-1

PRISMA (2015). PRISMA flow diagram. Retrieved September 14, 2019, from http://www.prisma-statement.org/PRISMAStatement/FlowDiagram

Rahma PA (2013). Implementasi Clinical Pathway Untuk Kendali Mutu dan Kendali Biaya Pelayanan Kesehatan (Implementation of Clinical Pathway for Quality Control and Cost Control of Health Services). Retrieved from https://www.mutupelayanankesehatan.net/19-headline/208-implementasi-clinical-pathway-untuk-kendalimutu-dan-kendali-biaya-pelayanankesehatan

Rotter T, Kugler J, Koch R, Gothe H, Twork S, Van Oostrum JM, Steyerberg EW (2008). A systematic review and metaanalysis of the effects of clinical pathways on length of stay, hospital costs and patient outcomes. BMC Health Services Research, 8: 1-15. https://doi.org/10.1186/1472-6963-8-265

Sung KH, Chung CY, Lee KM, Lee SY, Ahn S, Park S, Park MS, et al. (2013). 
Application of clinical pathway using electronic medical record system in pediatric patients with supracondylar fracture of the humerus: A before and after comparative study. BMC Medical Informatics and Decision Making, 13(1). https://doi.org/10.1186/1472-6947-13-87

Zhang W, Wang BY, Du XY, Fang WW, Wu H, Wang L, Zou XP, et al. (2019). Bigdata analysis: A clinical pathway on endoscopic retrograde cholangiopan- creatography for common bile duct stones. World Journal of Gastroenterology, 25(8): 1002-1011. https://doi.org/10.3748/wjg.v25.i8.1002

Zhu L, Li J, Li XK, Feng JQ, Gao JM. (2014). Impact of a Clinical Pathway on Hospital Costs, Length of Stay and Early Outcomes after Hepatectomy for Hepatocellular Carcinoma. Asian Pacific Journal of Cancer Prevention, 15(13): 5389-5393. https://doi.org/10.7314/apjcp.2014.15.13.5389 